\title{
Efficiency of Vegetable Oils in Wood Resistance to Cryptotermes brevis Termites
}

\author{
Sara Freitas de Sousa ${ }^{1}$ (D), Juarez Benigno Paes ${ }^{2}$ (D), \\ Marina Donaria Chaves Arantes ${ }^{3}$ (i), Dercilio Verly Lopes Junior ${ }^{4}(\mathbb{D})$ \\ Marcos Alves Nicácio ${ }^{5}$ (D) \\ ${ }^{1}$ Universidade Federal do Oeste do Pará - UFOPA, Santarém/PA, Brasil \\ ${ }^{2}$ Universidade Federal do Espírito Santo - UFES, Jerônimo Monteiro/ES, Brasil \\ ${ }^{3}$ Universidade Federal de São João Del Rei - UFSJ, Sete Lagoas/MG, Brasil \\ ${ }^{4}$ Mississippi State University - MSU, Starkville/MS, United States of America \\ ${ }^{5}$ Instituto Federal de Educação, Ciência e Tecnologia do Amapá - IFAP, Laranjal do Jari/AP, Brasil
}

\begin{abstract}
Natural products have been studied in order to ensure environmental sustainability, human health, and diminish the use of traditional products. The objective of this study was to evaluate the efficiency of pure andiroba (Carapa guianensis), copaiba (Copaifera langsdorffii) and jatropha (Jatropha curcas) oils and enriched with iodine $\left(\mathrm{I}_{2}\right)$ on the biological resistance of Pinus elliottii wood to dry-wood termites (Cryptotermes brevis). The oils were enriched with 1\%, 3\%, and 5\% of $\mathrm{I}_{2}$ and impregnated into the wood by cold immersion. The treated samples were subjected to volatilization and leaching. Volatilization and leaching did not affect the loss of mass caused by termites, except for treatments with pure and enriched with $1 \%$ iodine copaiba oil. Leached samples were more damaged. The addition of iodine to the oils resulted in a greater efficiency against termites. Andiroba ( $3 \%$ and $5 \% \mathrm{I}_{2}$ ) and jatropha oils (5\%) were the most efficient, providing total termite mortality.
\end{abstract}

Keywords: wood durability, biological testing, dry-wood termites. 


\section{INTRODUCTION}

Wood consumption mainly from planted forests has increased as a result of its use for producing cellulose pulp and energy. In addition to these uses, wood has been used by the reconstituted panels industry and for producing solid products, in which the species of the Eucalyptus and Pinus genera have the largest participation in the Brazilian forest market. These woods have an increasing demand in the market, however they are more propitious to biological degradation caused by xylophagous organisms when compared to those produced by natural forests, which compromises their natural durability and shelf-life (Paes et al., 2010a), thus requiring the use of chemicals for their protection.

Termites stand out among xylophagous insects, mainly due to the volume of wood consumed by them. Those which feed on dry wood are of importance, especially in tropical countries. As a result, several studies have been developed in order to test wood resistance and its industrialized products to such insects (Oliveira et al., 2017).

Several products are employed to increase the natural resistance of wood against xylophagous organisms such as chromated copper arsenate (CCA) and chromated copper borate (CCB); however, these chemical compounds may be harmful to man and the environment (Bossardi \& Barreiros, 2011). Thus, natural oils are being increasingly tested to enhance the biological resistance of wood such as candeia oil (Eremanthus erythropappus) and its by-products (Paes et al., 2010a; Teixeira et al., 2015), de neem oil (Azadirachta indica) (Machado et al., 2006; Paes et al., 2010b, 2011, 2012) and the oil from plants of the Brazilian Cerrado (Medeiros et al., 2016).

These natural products can ensure the sustainability of the environment, human health, and decrease the use of traditional products that contain toxic compounds in their formulation (Teixeira et al., 2015), mainly by improving the resistance to deterioration of the wood provided by them. Consequently, andiroba (Carapa guianensis), copaiba (Copaifera langsdorffii) and jatropha or pinhão manso (Jatropha curcas) oils are used as biodiesel, biolubricants, paints, varnishes and furniture polishes (Gonçalves, 2001; Arruda et al., 2004; Duque, 2004). In addition to being used as insecticides and fungicides (Freire et al., 2006; Deus et al., 2011;
Queiroga et al., 2012; Oliveira et al., 2013), they stimulate interest for studies on wood treatments for the furniture industry and civil construction.

Modern society has been paying more attention to environmental issues. Regarding environmental conservation, the search for clean technologies is constant in order to minimize the damage caused by the use of harmful and often toxic substances such as CCA and CCB (Appel et al., 2007; Bossardi \& Barreiros, 2011).

Iodine, its salts and isotopes are used in medicine in the therapy of thyroid diseases, and in several countries it is added to cooking salt to prevent goiters. Moreover, it is a bactericidal, fungicidal and poorly water-soluble agent (Moriya \& Módena, 2008). Due to the antifungal and insecticidal properties of iodine (Costa et al., 2003) and its low toxicity to humans and the environment (Takahashi et al., 1985), associated with its low solubility in water, it can present residual power in treated wood, which is of interest to the industry since the active principle of the product will protect the wood longer when exposed to environmental action.

As a result of the need to test new products in order to improve wood resistance to xylophagous organisms, the objective of this study was to evaluate the efficiency of pure andiroba (Carapa guianensis), copaiba (Copaifera langsdorffii) and jatropha or pinhão manso (Jatropha curcas) oils or enriched with iodine $\left(\mathrm{I}_{2}\right)$ for improving the biological resistance of Pinus elliottii wood to dry-wood termites.

\section{MATERIAL AND METHODS}

\subsection{Obtaining the vegetable oils}

The andiroba (Carapa guianensis), and copaiba (Copaifera langsdorffii) oils came from communities in the municipality of Santarém (latitude 2 $24^{\circ} 52^{\prime \prime}$ S and longitude $54^{\circ} 42^{\prime} 36^{\prime \prime} \mathrm{W}$ ), state of Pará, Brazil, a region with annual average rainfall of $1,920 \mathrm{~mm}$, with a dominantly hot and humid climate characteristic of tropical forests.

The jatropha or pinhão manso (Jatropha curcas) oil came from the Fazenda Tamanduá, located in the municipality of Santa Terezinha (latitude $7^{\circ} 5^{\prime} 19^{\prime \prime} S$ and longitude $37^{\circ} 27^{\prime} 23^{\prime \prime}$ W), state of Paraíba, Brazil, with a hot and dry semiarid climate and annual average rainfall less than $800 \mathrm{~mm}$. 


\subsection{Obtaining the wood and preparing the samples}

Pinus elliottii wood was obtained in the form of $10 \times 10 \times 300 \mathrm{~cm}$ (width $\times$ thickness $\times$ length) beams coming from a plantation at the age of 21 years, located in the Agroindustrial Complex Pindobas Ltda., municipality of Venda Nova do Imigrante, state of Espírito Santo, Brazil, (latitude $20^{\circ} 20^{\prime} 04^{\prime \prime}$ S and longitude $41^{\circ} 08^{\prime} 05^{\prime \prime} \mathrm{W}$ ). The beams were mechanically processed at the Wood Machining and Woodworking Laboratory, Department of Forest and Wood Sciences, Federal University of Espírito Santo, located in Jerônimo Monteiro, Espírito Santo state, for the removal of samples measuring $7.0 \times 2.3 \times 0.6 \mathrm{~cm}$ (longitudinal $\times$ radial $\times$ tangential), as recommended by the dry-wood termite test described by the Instituto de Pesquisas Tecnológicas (IPT, 1980).

The obtained samples were selected by discarding those that presented defects (nodes, resin bags and cracks), sanded and identified according to the treatment to be employed and the conditions of each test. Prior to treating the wood, the specimens were oven dried at $103 \pm 2{ }^{\circ} \mathrm{C}$ until reaching a constant mass, and the masses and volumes (mercury displacement) were verified. The masses after the treatments were also obtained to determine the retention $\left(\mathrm{kg} \mathrm{m}^{-3}\right)$ of the product in the wood.

\subsection{Impregnation and situations submitted to samples}

The cold immersion method was used for the wood impregnation, in which the samples were submerged into the oils (Table 1) until reaching retention of 50 to $70 \mathrm{~kg} \mathrm{~m}^{-3}$.

Table 1. Discrimination of the treatments used in the samples of Pinus elliotti.

\begin{tabular}{|cc|}
\hline Treatment & Discrimination \\
\hline 1 & Control (untreated wood samples) \\
\hline 3 & Pure andiroba oil \\
\hline 4 & Andiroba oil $+1 \%$ iodine \\
\hline 5 & Andiroba oil $+3 \%$ iodine \\
\hline 6 & Andiroba oil $+5 \%$ iodine \\
\hline 7 & Pure copaiba oil \\
\hline 8 & Copaiba oil $+1 \%$ iodine \\
\hline 9 & Copaiba oil $+5 \%$ iodine \\
\hline 10 & Pure jatropha oil \\
\hline 11 & Jatropha oil $+1 \%$ iodine \\
\hline 12 & Jatropha oil $+3 \%$ iodine \\
\hline 13 & Jatropha oil $+5 \%$ iodine \\
\hline
\end{tabular}

The treated samples were submitted to three situations (1 - Normal; 2 - Volatilized; and 3 - Leached).

In situation 1, the sample surfaces were dried after impregnation using absorbent paper, and then subjected to termites. In situation 2 , the impregnated samples were subjected to volatilization according to the methodology described by the American Society for Testing and Materials (ASTM, 2008a), in which the woods were immersed in distilled water for 2 hours, followed by exposure in a forced circulation oven at $48.9 \pm 1.1^{\circ} \mathrm{C}$ for 334 hours. Then they were exposed to the action of the insects.

For the leaching test (situation 3) the methodology described by Freitas (1970) was used, which consists of subjecting the specimens where the inflow and outflow of water is regulated to $400 \mathrm{~mL} \mathrm{~min}{ }^{-1}$ for 150 hours in a container. After this procedure the samples were conditioned for 15 days (temperature of $25 \pm 2{ }^{\circ} \mathrm{C}$ and $65 \pm 5 \%$ of relative humidity), and tested according to the dry-wood termite test.

\subsection{Dry-wood termites test}

The samples treated and submitted to the described situations (normal, volatilized or leached) were subjected to dry-wood termites (Cryptotermes brevis Walker), according to the methodology described by the IPT (1980). For this, four replicates per treatment (Table 1) and situation were used. The samples were grouped two by two, forming a set. A polyvinyl chloride (PVC) container with a diameter of $3.5 \mathrm{~cm}$ and $4.0 \mathrm{~cm}$ of height was fixed with paraffin in each set. Next, 40 termites were introduced into each container, being 39 worker termites and one soldier termite. Each set was arranged in a Petri dish to prevent insects from escaping (Figure 1). The test was performed in an airconditioned room $\left(27 \pm 2{ }^{\circ} \mathrm{C}\right.$ and $65 \pm 5 \%$ of relative humidity) for 45 days.

At the end of the experiment, the remaining termites were removed from the containers and counted again to evaluate the percentage of mortality and damage caused to the samples. To the damage was attributed a score: 0 (no damage - none), 1 (superficial damage), 2 (moderate damage), 3 (considerable damage), 4 (severe damage). The number of holes was also evaluated as recommended by the IPT (1980), as well as the loss of mass caused by termites to the samples (ASTM, 2008b), corrected for the loss of operational mass. 

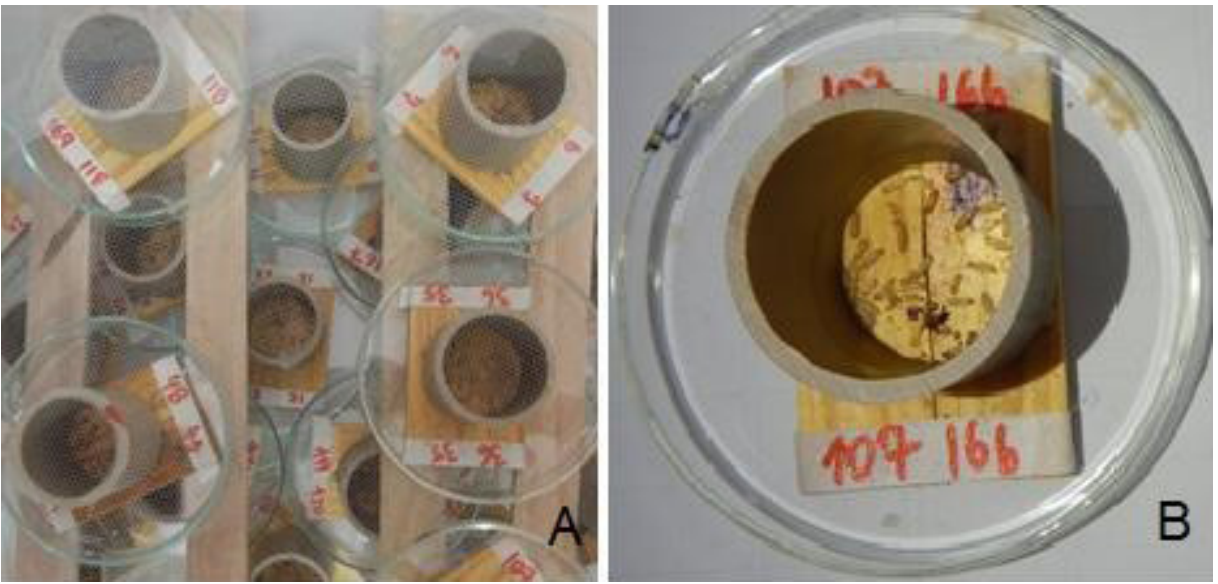

Figure 1. Resistance test to dry-wood termites (A) and detail of the assembly formed by the set of Pinus elliottii samples (B).

\subsection{Statistical analysis and evaluation of results}

The design was completely randomized with a factorial arrangement. The study evaluated the effects of the treatments (13 levels) and situations (three levels), a $13 \times 3$ factorial, totaling 39 treatments.

Data normality (Lilliefors test) and homogeneity of variances (Cochran test) were verified. In order to conduct a statistical analysis, the percentages of mass loss and mortality were transformed into arcsen [root (loss of mass or mortality/100)] and damage (score) in root (score +0.5 ). These transformations suggested by Steel \& Torrie (1980) were necessary to conduct homogeneity of the variances. The Scott-Knott test $(\mathrm{p}<0.05)$ for the factors and interaction detected as signified by the F-test $(\mathrm{p}<0.05)$ were employed for the analysis and evaluation of the tests.

\section{RESULTS AND DISCUSSION}

The analysis of variance of the mass loss data of the test specimens showed significant results by the F-test for the treatments, situations and for the interaction between these factors, which were sawn and analyzed (Table 2).

An improvement in the resistance of Pinus wood was observed when treated with the tested oils and solutions (enriched with $\mathrm{I}_{2}$ ). When analyzing the interaction between the treatment factors and the situation, it can be noted that the mass losses of the samples were generally not affected by volatilization or leaching, except for treatments 6 and 7, which correspond to pure copaiba oil and copaiba oil enriched with $1 \% \mathrm{I}_{2}$.

The treatments with andiroba oil, both pure (treatment 2 ) and enriched with $1 \%, 3 \%$ and $5 \% I_{2}$ (treatments 3, 4 and 5) and jatropha oil (treatments 10 to 13) did not statistically differ from one another in the three situations. The same did not occur for pure copaiba oil (treatment 6) or copaiba oil enriched with $1 \% \mathrm{I}_{2}$ (treatment 7). This may have occurred due to the ease of leaching or volatilization of copaiba oil in the impregnated wood, indicating that it should not be used in treating wood that is subject to inclement weather, except when enriched with 3 or $5 \% \mathrm{I}_{2}$

The mass losses of the wood treated with jatropha oil were lower for both the leached and volatilized conditions (treatments 10,11,12 and 13), statistically differing from other treatments. This indicates that this oil was more resistant to the volatilization and leaching effects, being more efficient than the others when exposed to such situations, regardless of the amount of $\mathrm{I}_{2}$ added to it.

An analysis of variance of the test data from the samples showed significant results by the F-test only for the treatments and the situation. A beneficial effect in the treated wood can be verified by the reduced damage in the specimens when compared to the control. In relation to the scores attributed to the damage caused by dry-wood termites, the greatest damage occurred in the wood without treatment, being considered as moderate to severe damage (Table 3). Usually a score 
Table 2. Comparison between mean mass losses caused by dry-wood termites as a function of the tested treatments and situations.

\begin{tabular}{|c|c|c|c|}
\hline \multirow{2}{*}{ Treatment } & \multicolumn{3}{|c|}{ Situation/Mass Loss (\%) } \\
\hline & 1 - Normal & 2 - Volatilized & 3 - Leached \\
\hline 1 - Control & $10.98 \mathrm{aA}$ & $12.17 \mathrm{aA}$ & $11.82 \mathrm{aA}$ \\
\hline 2 - Pure andiroba oil & $5.66 \mathrm{bA}$ & $6.51 \mathrm{bA}$ & $7.05 \mathrm{bA}$ \\
\hline 3 - Andiroba oil $+1 \% \mathrm{I}_{2}$ & $5.83 \mathrm{bA}$ & $5.86 \mathrm{bA}$ & $6.74 \mathrm{bA}$ \\
\hline 4 - Andiroba oil $+3 \% \mathrm{I}_{2}$ & $6.23 \mathrm{bA}$ & $6.23 \mathrm{bA}$ & $6.30 \mathrm{bA}$ \\
\hline 5 - Andiroba oil + 5\% $\mathrm{I}_{2}$ & $7.05 \mathrm{bA}$ & $6.25 \mathrm{bA}$ & $6.66 \mathrm{bA}$ \\
\hline 6 - Pure copaiba oil & $4.08 \mathrm{cC}$ & $6.09 \mathrm{bB}$ & $7.86 \mathrm{bA}$ \\
\hline 7 - Copaiba oil $+1 \% I_{2}$ & $5.39 \mathrm{bB}$ & $7.07 \mathrm{bA}$ & $6.84 \mathrm{bA}$ \\
\hline 8 - Copaiba oil $+3 \% I_{2}$ & $6.74 \mathrm{bA}$ & $6.92 \mathrm{bA}$ & $6.82 \mathrm{bA}$ \\
\hline 9 - Copaiba oil $+5 \% I_{2}$ & $6.58 \mathrm{bA}$ & $7.60 \mathrm{bA}$ & $6.89 \mathrm{bA}$ \\
\hline 10 - Pure jatropha oil & $4.04 \mathrm{cA}$ & $4.94 \mathrm{cA}$ & $5.33 \mathrm{cA}$ \\
\hline 11 - Jatropha oil + $1 \% \mathrm{I}_{2}$ & $4.69 \mathrm{cA}$ & $4.42 \mathrm{cA}$ & $5.12 \mathrm{cA}$ \\
\hline 12 - Jatropha oil + 3\% $I_{2}$ & $5.39 \mathrm{bA}$ & $4.62 \mathrm{cA}$ & $4.91 \mathrm{cA}$ \\
\hline 13 - Jatropha oil + $5 \% \mathrm{I}_{2}$ & $5.39 \mathrm{bA}$ & $5.05 \mathrm{cA}$ & $5.89 \mathrm{cA}$ \\
\hline
\end{tabular}

Means followed by the same lowercase letter in column or uppercase letters in the line do not differ from one another by the Scott-Knott test ( $\mathrm{p}>0.05)$.

Table 3. Comparison between mean damage (score) caused by dry-wood termites as a result of the tested treatments.

\begin{tabular}{|c|c|c|}
\hline Treatment & Damage (Score) & Classification \\
\hline 1 - Control & $2.45 \mathrm{a}$ & Moderate to considerable damage \\
\hline 2 - Pure andiroba oil & $0.33 \mathrm{c}$ & None to superficial damage \\
\hline 3 - Andiroba oil $+1 \% I_{2}$ & $0.25 \mathrm{c}$ & None to superficial damage \\
\hline 4 - Andiroba oil $+3 \% I_{2}$ & $0.31 \mathrm{c}$ & None to superficial damage \\
\hline 5 - Andiroba oil $+5 \% I_{2}$ & $0.52 \mathrm{c}$ & None to superficial damage \\
\hline 6 - Pure copaiba oil & $1.66 \mathrm{a}$ & Superficial to moderate damage \\
\hline 7 - Copaiba oil + $1 \% I_{2}$ & $1.18 \mathrm{~b}$ & Superficial to moderate damage \\
\hline 8 - Copaiba oil $+3 \% I_{2}$ & $1.06 \mathrm{~b}$ & Superficial to moderate damage \\
\hline 9 - Copaiba oil + $5 \% \mathrm{I}_{2}$ & $1.27 \mathrm{~b}$ & Superficial to moderate damage \\
\hline 10 - Pure jatropha oil & $1.22 \mathrm{~b}$ & Superficial to moderate damage \\
\hline 11 - Jatropha oil $+1 \% I_{2}$ & $0.70 \mathrm{c}$ & None to superficial damage \\
\hline 12 - Jatropha oil $+3 \% I_{2}$ & $1.12 \mathrm{~b}$ & Superficial to moderate damage \\
\hline 13 - Jatropha oil + $5 \% I_{2}$ & $0.89 \mathrm{~b}$ & None to superficial damage \\
\hline
\end{tabular}

Means followed by the same letter do not differ from one another by the Scott-Knott test $(\mathrm{p}>0.05)$.

of 4 (severe damage) is attributed to untreated pine wood, since it is considered susceptible to the termite used in the test (IPT, 1980).

The moderate to considerable damage observed for the non-impregnated Pinus elliottii wood may be related to the age of the trees and the proportion of late wood (summer wood) in the tested wood, which presents greater resistance to scarification, however with greater mass loss (Table 2), thus requiring the removal of a smaller volume of woody material to satisfy the insects' food need.

No significant difference between the damage to the control (control) and treatment 6 samples corresponding to pure copaiba oil was observed. The lowest waste was attributed to wood treated with andiroba oil, both pure and enriched with $1 \%, 3 \%$ and $5 \%$ (treatments 2, 3, 4 and 5), 
which did not statistically differ (from each other). When copaiba oil was enriched with iodine, it resulted in less damage to the wood when compared to control and treatment 6 . The addition of iodine in the case of termites can cause difficulties for them to scarify the wood, causing damage to the insects' jaw; a similar effect to that caused by silicates.

The damage observed for impregnated samples was lower than that found by Oliveira et al. (2017) for the wood of seven species of Eucalyptus coming from trees at 16 years, thus proving the improvement in the resistance of the impregnated samples, regardless of the oil and $\mathrm{I}_{2}$ percentage used.

Regarding the situation, the greatest damage was observed for wood subjected to leaching and volatilization (Table 4), since the samples submitted to such situations lose protective substances present in the oils, allowing greater attack by insects.

Table 4. Comparison between mean damage (score) for the dry-wood termite test for each situation.

\begin{tabular}{|cc|}
\hline Situation & Damage (Score) \\
\hline $\mathbf{3}$ - Leached & $1.19 \mathrm{a}$ \\
$\mathbf{2}$ - Volatilized & $1.05 \mathrm{a}$ \\
\hline $\mathbf{1}$ - Normal & $0.75 \mathrm{~b}$ \\
\hline
\end{tabular}

Means followed by the same letter do not differ from one another by the Scott-Knott test ( $p>0.05)$.
A score of 4.0 (severe damage) was attributed by Gonçalves \& Oliveira (2006) for the attack of Cryptotermes brevis to Pinus sp. wood, in addition to two holes in the samples of this wood being observed and termite mortality was $17.50 \%$, which differed from other species such as Australian cedar, cacunda, cupiúba, cedar rose and pequi. Oliveira et al. (2017) found severe damage (score 4) to Pinus sp. wood subjected to the same species of termites, with 15 holes and mortality of $34.4 \%$, which was similar to that in the wood of seven Eucalyptus species at 16 years of age.

Regarding the natural resistance of Eucalyptus grandis at four different ages (10, 14, 20 and 25 years) to the attack of dry-wood termites (Cryptotermes brevis), Silva et al. (2004) found that wood was highly susceptible to attack regardless of age, evidencing the low natural resistance of this species. The damage found for all the ages was similar to those found for Pinus elliottii wood, with a score of 4.0. The damage caused to Eucalyptus grandis wood was 3.0, 3.0, 3.2 and 4.0 for the ages of $20,25,14$ and 10 years, respectively.

With regard to termite mortality, an analysis of variance of the data showed significant results by the F-test for treatments, situations and for the interaction between treatment and situation, in which the wood was sawn and analyzed by the Scott-Knott test (Table 5).

Table 5. Comparison between mortality rates of dry-wood termites for the tested treatments and situations.

\begin{tabular}{|c|c|c|c|}
\hline \multirow{2}{*}{ Treatment } & \multicolumn{3}{|c|}{ Situation/Mortality (\%) } \\
\hline & 1 - Normal & 2 - Volatilized & 3 - Leached \\
\hline 1 - Control & $73.75 \mathrm{dA}$ & $55.00 \mathrm{cB}$ & $42.50 \mathrm{~dB}$ \\
\hline 2 - Pure andiroba oil & $93.75 \mathrm{bA}$ & $96.00 \mathrm{aA}$ & $95.00 \mathrm{aA}$ \\
\hline 3 - Andiroba oil $+1 \% I_{2}$ & $98.75 \mathrm{aA}$ & $91.25 \mathrm{aA}$ & $96.25 \mathrm{aA}$ \\
\hline 4 - Andiroba oil $+3 \% \mathrm{I}_{2}$ & $100.00 \mathrm{aA}$ & $92.50 \mathrm{aB}$ & $95.00 \mathrm{aB}$ \\
\hline 5 - Andiroba oil $+5 \% \mathrm{I}_{2}$ & $100.00 \mathrm{aA}$ & $95.00 \mathrm{aA}$ & $97.50 \mathrm{aA}$ \\
\hline 6 - Pure copaiba oil & $50.00 \mathrm{eB}$ & $78.75 \mathrm{bA}$ & $58.75 \mathrm{~dB}$ \\
\hline 7 - Copaiba oil $+1 \% I_{2}$ & $72.50 \mathrm{dA}$ & $63.75 \mathrm{cA}$ & $60.00 \mathrm{dA}$ \\
\hline 8 - Copaiba oil $+3 \% I_{2}$ & $71.25 \mathrm{~dB}$ & $95.00 \mathrm{aA}$ & $76.25 \mathrm{cB}$ \\
\hline 9 - Copaiba oil $+5 \% \mathrm{I}_{2}$ & $87.50 \mathrm{cA}$ & $83.75 \mathrm{bA}$ & $83.75 \mathrm{bA}$ \\
\hline 10 - Pure jatropha oil & $85.00 \mathrm{cA}$ & $45.00 \mathrm{cB}$ & $60.00 \mathrm{~dB}$ \\
\hline 11 - Jatropha oil + 1\% $I_{2}$ & $88.75 \mathrm{cA}$ & $90.00 \mathrm{aA}$ & $82.50 \mathrm{bA}$ \\
\hline 12 - Jatropha oil $+3 \% I_{2}$ & $95.00 \mathrm{bA}$ & $80.00 \mathrm{aA}$ & $93.75 \mathrm{aA}$ \\
\hline 13 - Jatropha oil $+5 \% I_{2}$ & $100.00 \mathrm{aA}$ & $76.25 \mathrm{bB}$ & $93.75 \mathrm{aA}$ \\
\hline
\end{tabular}

Means followed by the same lowercase letter in column or uppercase letters in the line do not differ from one another by the Scott-Knott test $(\mathrm{p}>0.05)$. 
By analyzing the interaction, it was verified that the control (treatment 1) had lower mortality, thus confirming the effect of the treatments with the oils since the mortality percentage of termites submitted to the treated wood was higher. Thus it can be concluded that the oils and solutions with $\mathrm{I}_{2}$ were possibly toxic to termites (Table 5), in accordance to the reports of Gonçalves et al. (2013) and Paes et al. (2013), who found that species with higher levels of extractives (in the case of this study, the oils tested) or ashes (in the case $\mathrm{I}_{2}$ ) caused higher mortality of the insects.

It can be highlighted that the increase of the iodine concentration in the oils increased the termites' mortality, proving the insecticidal action of this product. The treatments with andiroba oil (treatments 2, 3 and 5) had no effect of volatilization and leaching, as well as treatments 7, 9, 11 and 12. Overall, termite mortality under the normal situation was higher than in other situations (leached or volatilized).

A total of $100 \%$ of termite death was verified when androba oil was enriched with 3 and 5\% $\mathrm{I}_{2}$ (treatments 4 and 5, situation 1). These results did not differ statistically from treatment 13 , situation 1, demonstrating that jatropha oil was also lethal to termites when enriched with $5 \% \mathrm{I}_{2}$. As reported by Costa et al. (2003), this proves the efficiency of iodine compounds against xylophagous termites.

A mass loss of $18.13 \%$ and mortality of $12.50 \%$ was found for Pinus taeda wood, for which was attributed a score of 3.0, indicating a considerable damage according to the IPT (1980) and low wood resistance.

Brocco et al. (2017) obtained values of $1.76 \%$ of mass loss, in addition to a damage (score) of 2.28 for untreated Pinus elliottii wood. Termite mortality was classified as moderate, with a mean of $44.50 \%$. All samples were perforated, with the number of holes ranging from 1 to 2 .

No holes were found in samples of wood treated with oils or solutions, except for a sample treated with pure copaiba oil in the leached situation. The Pinus elliottii wood used as a control (leached situation) averaged one hole per sample. No holes were found for normal and volatilized situations.

Thus, even in cases where the treated samples were subjected to leaching or volatilization, the oils and $\mathrm{I}_{2}$ concentrations improved the biological resistance of
Pinus elliottii wood to dry-wood termites. The results obtained are of interest for the protection of wood since, in addition to providing adequate protection, the tested products have low harmfulness to humans, which is a positive factor for this branch of activity because dry-wood termites preferentially attack residential and office furniture.

\section{CONCLUSIONS}

The lowest mass losses were found for the treatment with pure jatropha oil or enriched with $\mathrm{I}_{2}$, regardless of the proportion used, and its protective effect was not influenced by volatilization or leaching.

The lowest damage was observed for the treatment with pure and enriched andiroba oil (regardless of the $\mathrm{I}_{2}$ concentration), as well as for the jatropha oil $+1 \%$ $\mathrm{I}_{2}$. The damage was higher in the samples subjected to volatilization or leaching.

Wood treated with andiroba oil enriched with 3\% and $5 \% \mathrm{I}_{2}$ provided total mortality to termites, as well as jatropha oil with $5 \% \mathrm{I}_{2}$. This proves the efficacy of these oils on the tested dry-wood termites and the improvement in their efficiency with the addition of $\mathrm{I}_{2}$.

\section{ACKNOWLEDGEMENTS}

Brazilian Federal Agency for Support and Evaluation of Graduate Education (CAPES) by granting scholarship to the first, fourth and fifth article authors.

\section{SUBMISSION STATUS}

Received: 19 july, 2017

Accepted: 15 mar., 2018

\section{CORRESPONDENCE TO}

\section{Juarez Benigno Paes}

Universidade Federal do Espírito Santo - UFES,

Av. Governador Lindemberg, 316, Centro, CEP 29550-000, Jerônimo Monteiro, ES, Brasil e-mail: jbp2@uol.com.br

\section{FINANCIAL SUPPORT}

Nothing to declare. 


\section{REFERENCES}

American Society for Testing and Materials - ASTM. ASTM D-1413: standard test method for wood preservatives by laboratory soil-block cultures. West Conshohocken: ASTM; 2008a. 7 p.

American Society for Testing and Materials - ASTM. ASTM D-2017: standard method of accelerated laboratory test of natural decay resistance of woods. West Conshohocken: ASTM; 2008b. 5 p.

Appel JSL, Terescova V, Rodrigues VCB, Vargas VMF. Aspectos toxicológicos do preservativo de madeira CCA (arseniato de cobre cromatado): revisão. Revista Brasileira de Toxicologia 2007; 19(1): 33-47.

Arruda FP, Beltrão NEM, Andrade AP, Pereira WE, Severino LS. Cultivo de pinhão manso (Jatropha curca L.) como alternativa para o semi-árido nordestino. Revista Brasileira de Olericultura Fibrose 2004; 8(1): 789-799.

Bossardi K, Barreiros RM. Produtos naturais como preservantes para madeiras de rápido crescimento: uma revisão. Ciência da Madeira 2011; 2(2): 109-118. http:// dx.doi.org/10.12953/2177-6830.v02n02a05.

Brocco VF, Paes JB, Costa LG, Brazolin S, Arantes MDC. Potential of teak heartwood extracts as a natural wood preservative. Journal of Cleaner Production 2017; 142(4): 2093-2099. http://dx.doi.org/10.1016/j.jclepro.2016.11.074.

Costa AF, Gonçalez JC, Vale AT. Eficiência de um composto de iodo orgânico contra fungos apodrecedores de madeiras e térmitas. Ciência Florestal 2003; 13(1): 145-152.

Deus RJA, Alves CN, Arruda MSP. Avaliação do efeito antifúngico do óleo resina e do óleo essencial de copaíba (Copaifera multijuga Hayne). Revista Brasileira de Plantas Medicinais 2011; 13(1): 1-7. http://dx.doi.org/10.1590/ S1516-05722011000100001.

Duque JG. O nordeste e as lavouras xerófilas. 4. ed. Fortaleza: Banco do Nordeste do Brasil; 2004. 330 p.

Freitas AR. Métodos de avaliação de preservativos em laboratório. Preservação de Madeiras 1970; 1(3): 151-173.

Freire DCB, Brito-Filha CRC, Carvalho-Zilse GA. Efeito dos óleos vegetais de andiroba (Carapa sp.) e Copaíba (Copaifera sp.) sobre forídeo, pragas de colméias, (Diptera: Phoridae) na Amazônia Central. Acta Amazonica 2006; 36(3): 3-8. http://dx.doi.org/10.1590/S0044-59672006000300012.

Gonçalves FG, Oliveira JTS. Resistência ao ataque de cupim de madeira seca (Cryptotermes brevis) em seis espécies florestais. Cerne 2006; 12(1): 80-83.

Gonçalves FG, Pinheiro DTC, Paes JB, Carvalho AG, Oliveira GL. Durabilidade natural de espécies florestais madeireiras ao ataque de cupim de madeira seca. Floresta e Ambiente 2013; 20(1): 110-116. http://dx.doi.org/10.4322/ floram.2012.063.
Gonçalves VA. Levantamento de mercado de produtos florestais não-madeireiros: Floresta Nacional do Tapajós. Santarém: Promanejo-Ibama; 2001.

Instituto de Pesquisas Tecnológicas - IPT. Divisão de Madeira. DIMAD D-2: ensaio acelerado de laboratório da resistência natural ou madeira preservada ao ataque de térmitas do gênero Cryptotermes. São Paulo: IPT; 1980. 1 p. (Publicação IPT; no. 1157).

Machado GO, Calil C Jr, Polito W, Pawlicka A. Preservante natural de madeira para uso na construção civil: óleo de neem. Minerva 2006; 3(1): 1-8.

Medeiros FCM, Gouveia FN, Bizzo HR, Vieira RF, Del Menezzi CHS. Fungicidal activity of essential oils from Brazilian Cerrado species against wood decay fungi. International Biodeterioration \& Biodegradation 2016; 114: 87-93. http://dx.doi.org/10.1016/j.ibiod.2016.06.003.

Moriya T, Módena JLP. Assepsia e antissepsia: técnicas de esterilização. Medicina 2008; 41(3): 265-273.

Oliveira HN, Santana AG, Antigo MR. Atividade inseticida dos óleos de pinhão-manso (Jatropha curcas L.) e neem (Azadirachta indica a. juss.) em ovos de Diatraea saccharalis fabr., 1794 lepidoptera: crambidae. Embrapa Agropecuária Oeste 2013; 80(2): 229-232.

Oliveira JTS, Paes JB, Vidaurre GB. Resistência biológica da madeira de espécies de eucalipto ao ataque de cupim de madeira seca. Scientia Forestalis 2017; 45(113): 145-150. http://dx.doi.org/10.18671/scifor.v45n113.14.

Paes JB, Fonseca CMB, Lima CR, Souza AD. Eficiência do óleo de candeia na melhoria da resistência da madeira de sumaúma a cupins. Cerne 2010a; 16(2): 217-225. http:// dx.doi.org/10.1590/S0104-77602010000200014.

Paes JB, Medeiros PN No, Lima CR, Freitas MF, Diniz CEF. Efeitos dos extrativos e cinzas na resistência natural de quatro madeiras a cupins xilófagos. Cerne 2013; 19(3): 399405. http://dx.doi.org/10.1590/S0104-77602013000300006.

Paes JB, Souza AD, Lima CR, Medeiros PN No. Eficiência dos óleos de nim e mamona contra cupins xilófagos em ensaio de alimentação forçada. Cerne 2010b; 16(1): 105113. http://dx.doi.org/10.1590/S0104-77602010000100012.

Paes JB, Souza AD, Lima CR, Medeiros PN No. Eficiência dos óleos de nim (Azadirachta indica) e de mamona (Ricinus communis) na melhoria da resistência da madeira de sumaúma (Ceiba pentandra) ao cupim Nasutitermes corniger em ensaio de preferência alimentar. Revista Árvore 2011;35(3, Suppl 1): 751-758. http://dx.doi.org/10.1590/ S0100-67622011000400020.

Paes JB, Souza AD, Lima CR, Souza PF. Eficiência dos óleos de nim (Azadirachta indica) e mamona (Ricinus communis) na resistência da madeira de sumaúma (Ceiba pentandra) a fungos xilófagos em simuladores de campo. Ciência Florestal 2012; 22(3): 617-624. http://dx.doi. org/10.5902/198050986627. 
Queiroga MFC, Gomes JP, Almeida FAC, Pessoa EB, Alves NMC. Aplicação de óleo no controle de Zabrotes subfasciatus e na germinação de Phaseolus vulgaris. Revista Brasileira de Engenharia Agrícola e Ambiental 2012; 16(7): 777-783. http://dx.doi.org/10.1590/S141543662012000700011 .

Silva JC, Caballeira Lopez AG, Oliveira JTS. Influência da idade na resistência natural da madeira de Eucalyptus grandis W. Hill ex. Maiden ao ataque de cupim de madeira seca (Cryptotermes brevis). Revista Árvore 2004; 28(4): 583-587. http://dx.doi.org/10.1590/S010067622004000400012 .
Steel RGD, Torrie JH. Principles and procedures of statistic: a biometrical approach. 2 nd ed. New York: McGraw-Hill; $1980.633 \mathrm{p}$.

Takahashi M, Tsunoda K, Imamura Y, Adachi A, Nishimoto $\mathrm{K}$. Studies on the production of preservative-treated plywood. (1) Preservative effectiveness of glue-line treated plywood with low toxicity chemicals. Mokuzai Hozon 1985; 11(2): 11-24.

Teixeira JG, Latorraca JVF, Trevisan H, Paes JB. Eficiência do óleo de neem e dos resíduos de candeia sobre a inibição do desenvolvimento de fungos xilófagos. Scientia Forestalis 2015; 43(106): 417-426. 